\title{
SPRAY CONE ANGLE AND AIR CORE DIAMETER OF HOLLOW CONE SWIRL ROCKET INJECTOR
}

\author{
Ahmad Hussein Abdul Hamid, Rahim Atan, \\ MOHD HAFIZ MOHD NOH AND HELMI RASHID \\ Faculty of Mechanical Engineering, University Technology MARA, 40450, \\ Shah Alam, Selangor, Malaysia. \\ hussein@salam.uitm.edu.my
}

\begin{abstract}
$\boldsymbol{A B S T R A C T : F u e l ~ i n j e c t o r ~ f o r ~ l i q u i d ~ r o c k e t ~ i s ~ a ~ v e r y ~ c r i t i c a l ~ c o m p o n e n t ~ s i n c e ~ t h a t ~ s m a l l ~}$ difference in its design can dramatically affect the combustion efficiency. The primary function of the injector is to break the fuel up into very small droplets. The smaller droplets are necessary for fast quiet ignition and to establish a flame front close to the injector head, thus shorter combustion chamber is possible to be utilized. This paper presents an experimetal investigation of a mono-propellant hollow cone swirl injector. Several injectors with different configuration were investigated under cold flow test, where water is used as simulation fluid. This investigation reveals that higher injection pressure leads to higher spray cone angle. The effect of injection pressure on spray cone angle is more prominent for injector with least number of tangential ports. Furthermore, it was found that injector with the most number of tangential ports and with the smallest tangential port diameter produces the widest resulting spray. Experimental data also tells that the diameter of an air core that forms inside the swirl chamber is largest for the injector with smallest tangential port diameter and least number of tangential ports.
\end{abstract}

ABSTRAK:Injektor bahan api bagi roket cecair merupakan satu komponen yang amat kritikal memandangkan perbezaan kecil dalam reka bentuknya akan secara langsung mempengaruhi kecekapan pembakaran. Fungsi utama injektor adalah untuk memecahkan bahan api kepada titisan yang amat kecil. Titisan kecil penting untuk pembakaran pantas secara senyap dan untuk mewujudkan satu nyalaan di hadapan, berhampiran dengan kepala injektor, maka kebuk pembakaran yang lebih pendek berkemungkinan dapat digunakan. Kertas kerja ini mebentangkan satu penyelidikan eksperimental sebuah injektor ekabahan dorong geronggang kon pusar. Beberapa injektor dengan konfigurasi berbeza telah dikaji di bawah ujian aliran sejuk, di mana air digunakan sebagai bendalir simulasi. Kajian ini mendedahkan bahawa suntikan bertekanan tinggi menghasilkan sudut semburan kon yang besar. Kesan tekanan suntikan ke atas sudut semburan kon lebih ketara pada injektor yang mempunyai lubang tangen yang kurang tambahan pula, injektor yang mempunyai jumlah lubang tangen yang paling banyak dan lubang tangen berdiameter paling kecil menghasilkan semburan yang paling lebar. Data eksperimental juga menunjukkan bahawa diameter teras udara terbesar terhasil di dalam kebuk pusar injektor yang mempunyai diameter lubang tangen terkecil dan jumlah lubang tangen yang paling kurang.

KEYWORDS: swirl spray;air core diameter;spray cone angle; rocket injector 


\section{INTRODUCTION}

Propellant injector is one of the most crucial part in liquid propellant rocket as it will determine the overall combustion efficiency and thrust produced. The main function of rocket injector is to atomize the fuel to a very fine droplets. It is known that one of the methods to improve combustion effiency of liquid fuel is to reduce the droplet size and hence to improve the quality of atomization [1].

The injector is the swirl type, where the propellant enters the swirl chamber at tangential component of velocity. There are several reasons of selecting a spray type fuel injector instead of a impinge type. First it will produce smaller fuel droplets that are readily vaporized and enhance mixing with the oxidizer, thus making the combustion process more efficient. The finely atomized liquid kerosene also expands the exposed surface which is necessary for easy ignition and to establish a flame front close to the injector face, thus a shorter combustion chamber is possible to be utilized. The larger droplets take longer time to burn and thus a longer combustion chamber is required, i.e. extra cost. Comparative analysis of different types of injectors shows that swirl injectors have strong advantages over other types of injectors [2]. Secondly, the fuel spray will provide liquid film cooling by means of excess fuel at the chamber inner wall. The excess fuel will form a thin layer of fluid over the wall and hence reduce the heat transfer to the gas-side wall of the combustion chamber. Lastly, the spray type injector will produce high radial velocity component of propellant which will increase the resident time of fuel in the combustion chamber that allow more time for the propellant to mix and burn.

Since only fuel is introduced into combustion chamber through this injector, it is considered as a mono-propellant type injector. The advantage of a mono-propellant injector lies on its simple, compact design which allows placement of the oxidizer and fuel injectors nearby to provide better mixing [2]. The other type of jet-swirl injector is a dual-propellant swirl injector, where both fuel and oxidizer is premixed in the swirl chamber and it is not to be discussed in detail.

In the injector, propellant is forced under high pressure to enter a swirl chamber through a set of tangential ports to create a high rotational velocity within the swirl chamber. Hence, the atomizer is also called a swirl injector. The propellant then moves forward out of the orifice in the form of a tube. The tube becomes a cone shaped film of propellant as it emerges from the orifice, ultimately stretching to a point where it ruptures and throws off finely atomized and sufficiently diffused droplets for adequate mixing with the oxidizer. Fig. 1 shows a schematic of the swirl injector geometry and also illustrates the spray pattern.

Due to tangential entry, an air-cored vortex flow of liquid takes place in the nozzle and the liquid comes out of the orifice in the form of hollow cone spray. It is noted that in the hollow cone spray, the concentration of droplets is at the outer edge with little or no fuel at the center. Hollow cone spray injector has a wide application in spacecraft injector [3].

This paper summarizes injector testing effort that evaluated a swirl injector using water as the working fluid. The injector is intended to introduce the flow into the combustion chamber before impinge with oxidizer. In other words, the injector provides external mixing, which prevent the oxidizers from penetrating the fuel supply line through the entire parts of injector elements. 


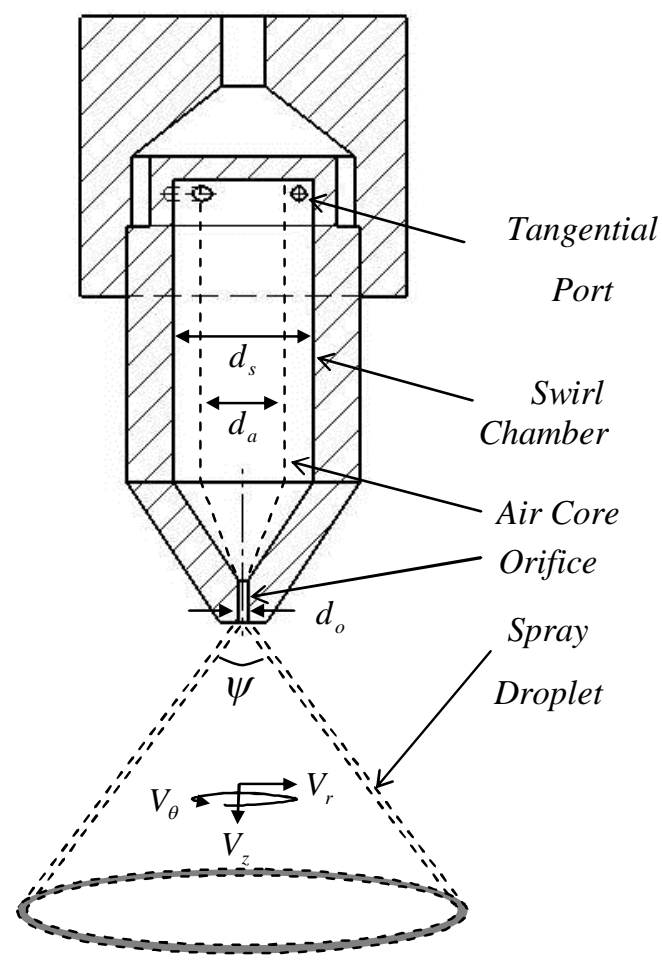

Fig. 1: Schematic sectioning of hollow cone swirl injector.

A number of injectors of geometrical shape as shown in Fig. 1 with different physical dimensions were fabricated from Perspex. The geometrical dimensions of the injectors tested are given in Table 1.

Table 1 Injector's specification.

\begin{tabular}{|c|c|c|c|c|}
\hline $\begin{array}{l}\text { Injector } \\
\text { number }\end{array}$ & $\begin{array}{l}\text { No. of tangential } \\
\text { port, } n\end{array}$ & $\begin{array}{l}\text { Tangential port } \\
\text { diameter, } d_{p} \\
(\mathbf{m m})\end{array}$ & $\begin{array}{l}\text { Swirl chamber } \\
\text { diameter, } d_{s} \\
(\mathrm{~mm})\end{array}$ & $\begin{array}{l}\text { Orifice } \\
\text { diameter, } d_{0} \\
(\mathbf{m m})\end{array}$ \\
\hline 1 & 2 & \multirow{5}{*}{1} & \multirow{7}{*}{30} & \multirow{7}{*}{2} \\
\hline 2 & 3 & & & \\
\hline 3 & 4 & & & \\
\hline 4 & 5 & & & \\
\hline 5 & 6 & & & \\
\hline 6 & \multirow[b]{2}{*}{4} & 2 & & \\
\hline 7 & & 3 & & \\
\hline
\end{tabular}




\section{LITERATURE REVIEW}

Most of the works available in the literature in the area of liquid atomization intended to predict the characteristics of swirl injector towards a better fundamental understanding of liquid atomization phenomena.Two important performance parameters are the spray cone angle and air core diameter that produced from the swirl injector. The size of the air core determines the effective flow area at the discharge orifice and thus controls the coefficient of discharge, which is one of the most important parameter of atomizer [4]. Another important performance parameter is the spray cone angle that determine the coverage and dispersion of spray in the surrounding ambiance or combustion chamber.

Laryea and No [1] have studied the relationship between applied voltage and injection pressure on liquid breakup length and spray angle of charge-injected electrostatic pressure swirl nozzle. They reported that an increase in applied voltage and injection pressure increases the value of spray cone angle.

Recently, an experimental investigation on the breakup length and spray cone of swirl spray with different injection pressure had been done by Hussein and Atan [5]. They concluded that higher injection pressure leads to wider spray cone angle. However, at higher injection pressure, the injectors experience slight decreases in spray cone angle as the liquid film at the injector outlet contracted.

Earlier numerical investigation done by Datta and Som [4] have found that with the increase in the liquid flow rate at its lower range there occurs a sharp increase in spray cone angle but it become independent at the high range of flow rate $\left(\mathrm{Q}>1 \times 10^{5} \mathrm{~m}^{3} \mathrm{~s}^{-1}\right)$. This result is in agreement with the work of Halder, Dash and Som [3]. They observed that the spray cone angle remain almost constant with the Reynolds number of the flow at inlet to the injector.

\section{EXPERIMENTATION}

All injectors were cold-tested using water at room temperature to define the pressure drop and spray pattern characteristics. An experimental test rig was constructed to measure the spray cone angle and air core diameter for different injection pressure. A schematic diagram of the test rig is shown in Fig. 2. Compressed air was used to pressurize the water tank. The supply water pressure was controlled by a single ball valve and measured by bourdon type pressure gauge. The volume flow rate of the water was varied according to injection pressure. The injector nozzle is mounted downward on a vertical plane, so that the water spray is injected directly into a basin at the ambient condition.

A cold flow injection test is an alternative to static firing test, where the original propellants are replaced by a simulated fluid which can be water or other liquids. It is a preliminary investigation of the swirl injector performance. The advantage of cold flow test is that the pure fluid atomization, jet break-up and jet stability of swirl injection can be identified and distinguished easily compared to more complex injection and chemical reaction of the firing test. Figure 3 shows the typical photograph taken during cold flow test and the experimental setup. It is important to understand the characteristics of the resulting spray field as it has a significant impact on the combustion stability as well as the propulsion efficiency 
[6]. Large-amplitude combustion oscillations lead to performance degradation, unacceptable noise levels, and structural damage.

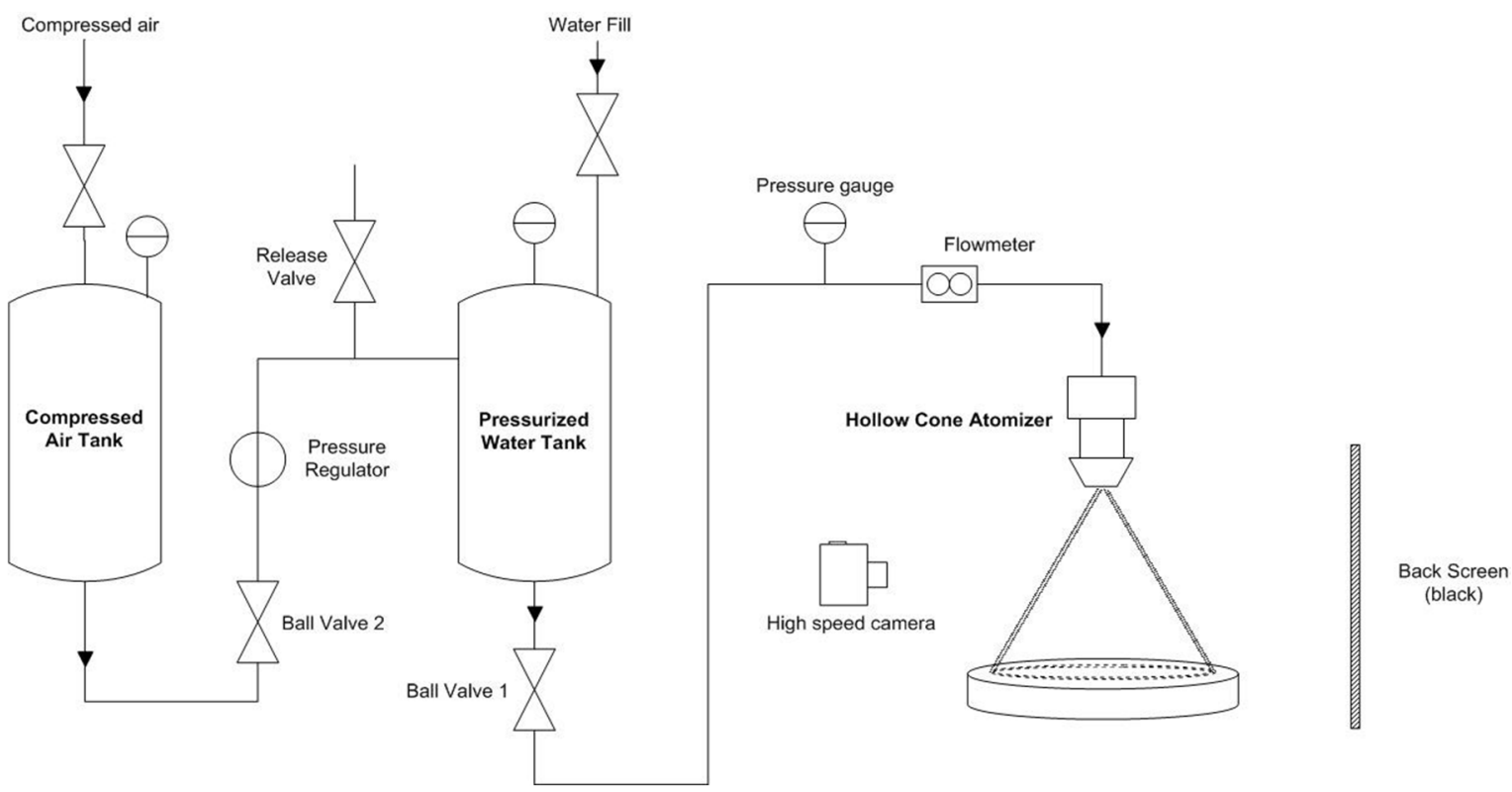

Fig. 2: Line diagram of the experimental setup.

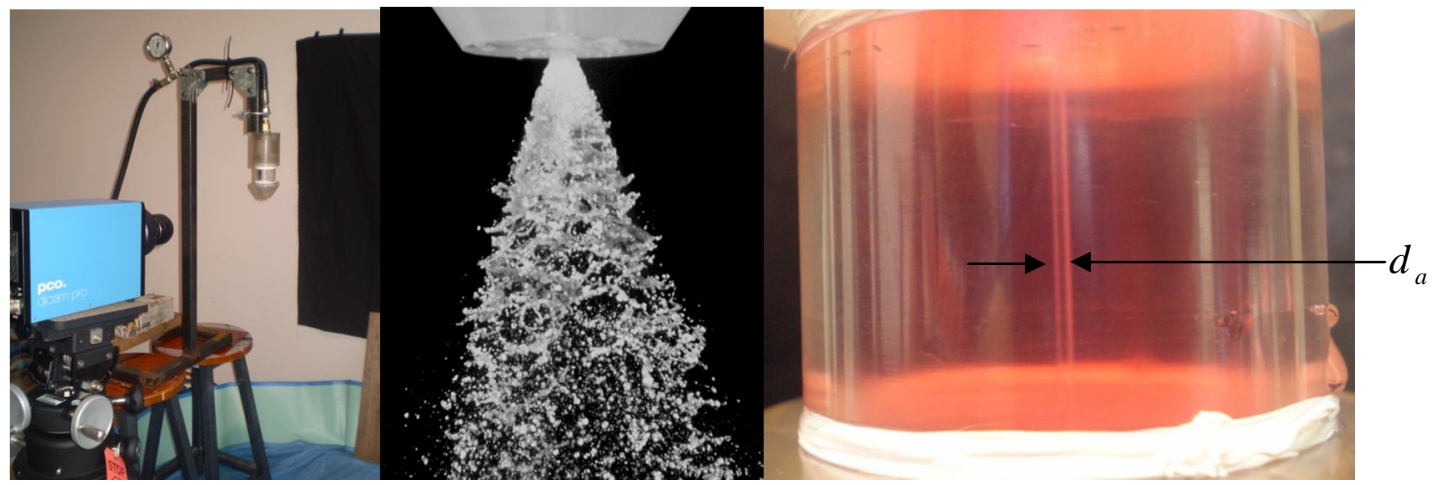

Fig. 3: Typical image of cold flow test.

\section{RESULTS AND DISCUSSION}

A fully developed spray was formed for all injectors at the highest tested injection pressure of 7 bar, as shown in Fig. 4.

The results of spray cone angle at different injection pressure and number of tangential ports is given in Fig. 5. Referring to the figure, it can be concluded that an increase in injection pressure increased the spray cone angle. It was also observed that the injector with the most number of tangential ports produced the widest spray for all injection pressure. This is because injector with more tangential port has the highest azimuthal velocity component which tends to widen the liquid film. However, for injector with 4 tangential ports, an additional tangential port does not increase the spray cone angle significantly for all tested 
pressure range. Furthermore, it can be seen that at an injection pressure higher than 4 bar, the spray cone angle is almost uninfluenced by the injection pressure.

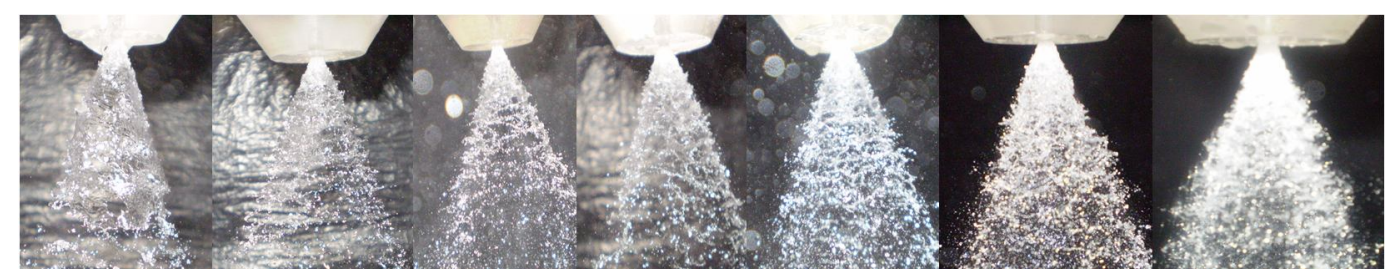

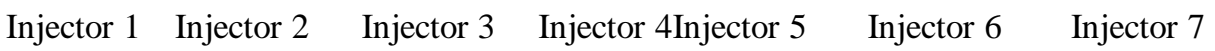

Fig. 4: Typical photographs at injection pressure of 7 bar.

The results of spray cone angle at different injection pressure and number of tangential ports is given in Fig. 5. Referring to the figure, it can be concluded that an increase in injection pressure increased the spray cone angle. It was also observed that the injector with the most number of tangential ports produced the widest spray for all injection pressure. This is because injector with more tangential port has the highest azimuthal velocity component which tends to widen the liquid film. However, for injector with 4 tangential ports, an additional tangential port does not increase the spray cone angle significantly for all tested pressure range. Furthermore, it can be seen that at an injection pressure higher than 4 bar, the spray cone angle is almost uninfluenced by the injection pressure.

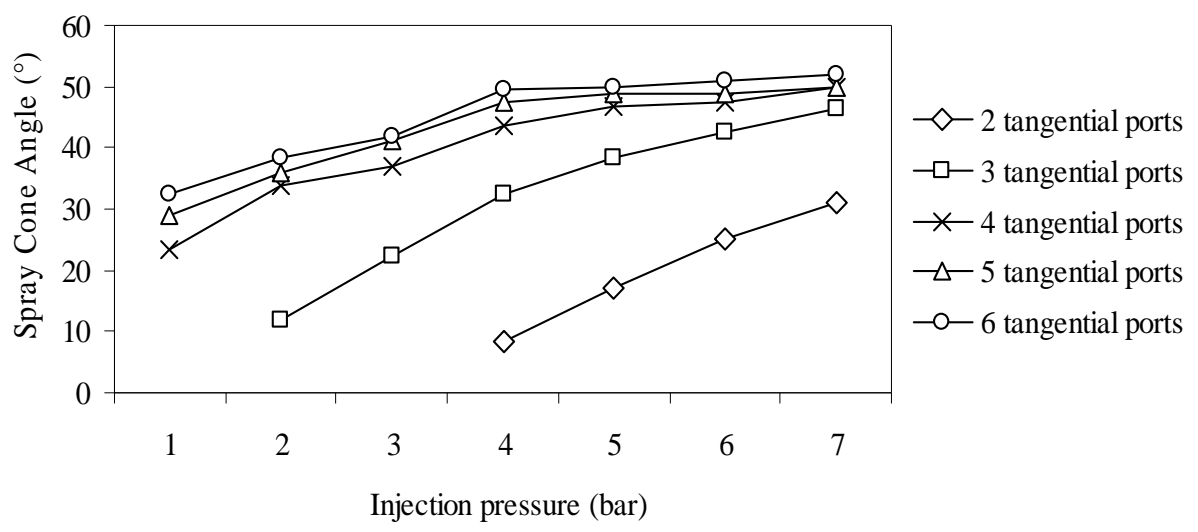

Fig. 5: Effects of injection pressure and number of tangential ports on spray cone angle.

It is also important to mention that there are no spray cone angle readings taken for injector with 2 and 3 tangential ports at lower range of injection pressure. It is because the sprays are not fully developed at low injection pressure. Take injector 2 for example, at injection pressure of $1 \mathrm{bar}$, the spray is in distorted pencil form and the spray is in onion stage at injection pressure of 2 bar. At injection pressure of 3 bar, both injector 2 and injector 3 produces tulip stage spray (Fig. 6). 


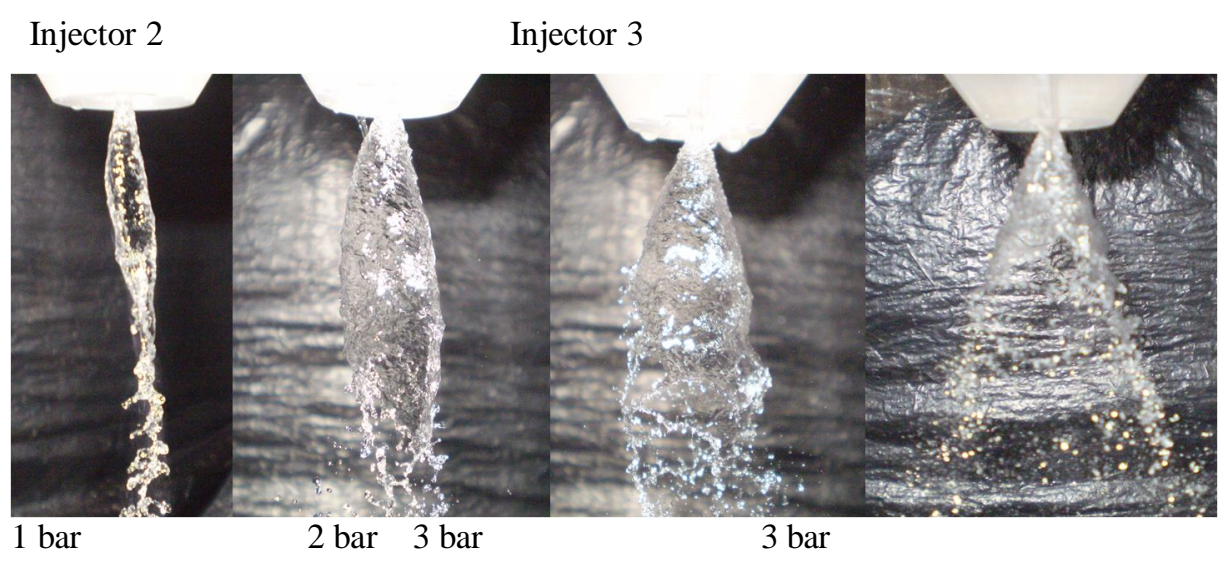

Fig. 6: Different stages of sprays.

Figure 7 shows the relationship between air core diameter, number of tangential ports and injection pressure. In general, air core diameter increased with an increase in injection pressure. This occurrence may be due to the increased azimuthal velocity of water stream exiting from the tangential ports with an increase of injection pressure, which subsequently increase the tendency for larger air core diameter. Furthermore, greater number of tangential ports leads to larger air core diameter at injection pressure less than 4 bar. However, at injection pressure higher than 4 bar, injector with 3 tangential ports produces larger air core diameter as compared to the one with 4 tangential ports. The reason is that less number of tangential ports at higher injection pressure contributes to higher swirling strength of flow inside the injector and hence developing larger air core diameter.

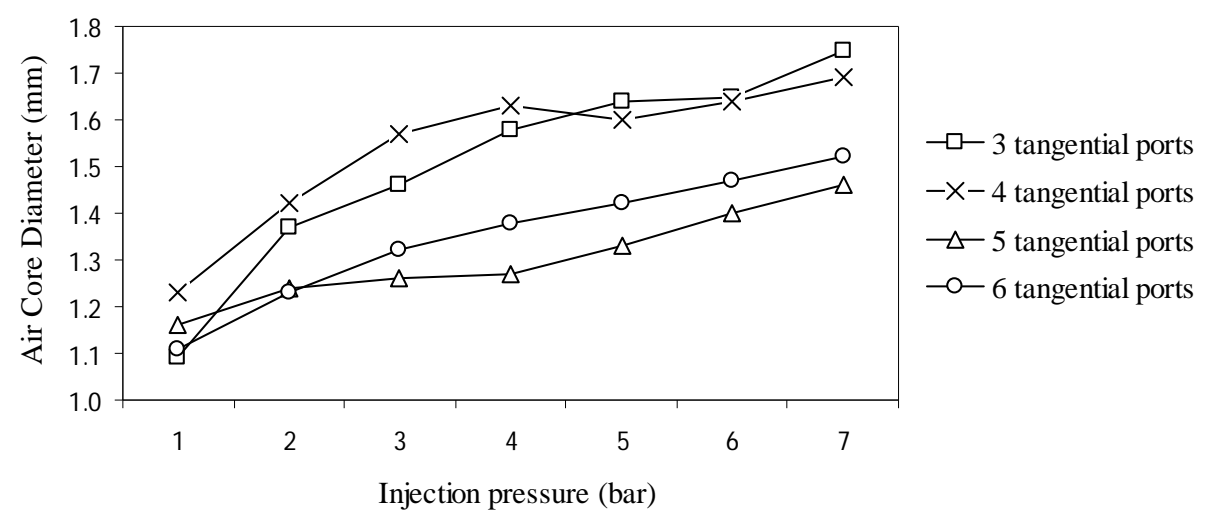

Fig. 7: Effects of injection pressure and number of tangential ports on air core diameter.

The relationship between spray cone angle, tangential port diameter and injection pressure is presented in Fig. 8. It can be seen that widest spray is produced by the injector with smallest tangential port for all injection pressure tested. This trend of variation can be attributed to the fact that the stream from the larger tangential ports increase the resistance offered by the injector to the swirling motion inside it and finally results in lower value of spray cone angle. 


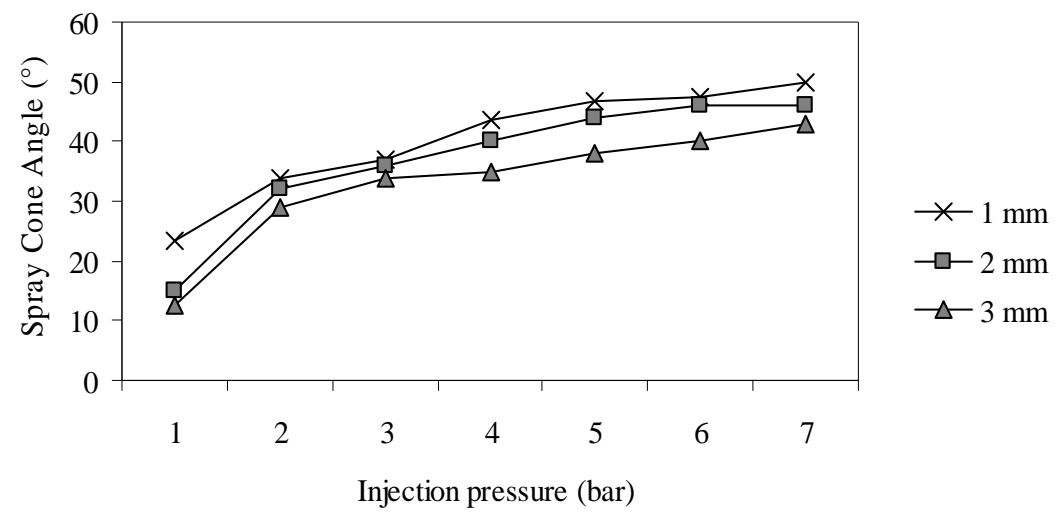

Fig. 8: Effects of injection pressure and diameter of tangential ports on spray cone angle.

Furthermore, a larger tangential port is accompanied by an increase in stream flow rate into the swirling chamber. That is why the diameter of air core developed is smallest inside the injector with largest tangential port (refer to Fig. 9). It is also can be concluded that the air core diameter is almost uninfluenced by injection pressure for small tangential port. It should be noted that there is no air core diameter readings is recorded for $3 \mathrm{~mm}$ tangential port diameter at injection pressure lower than 4 bar due to very low swirling strength of flow inside the injector and thus causes the air core to vibrate. The uncertainty of measurements is high under this condition.

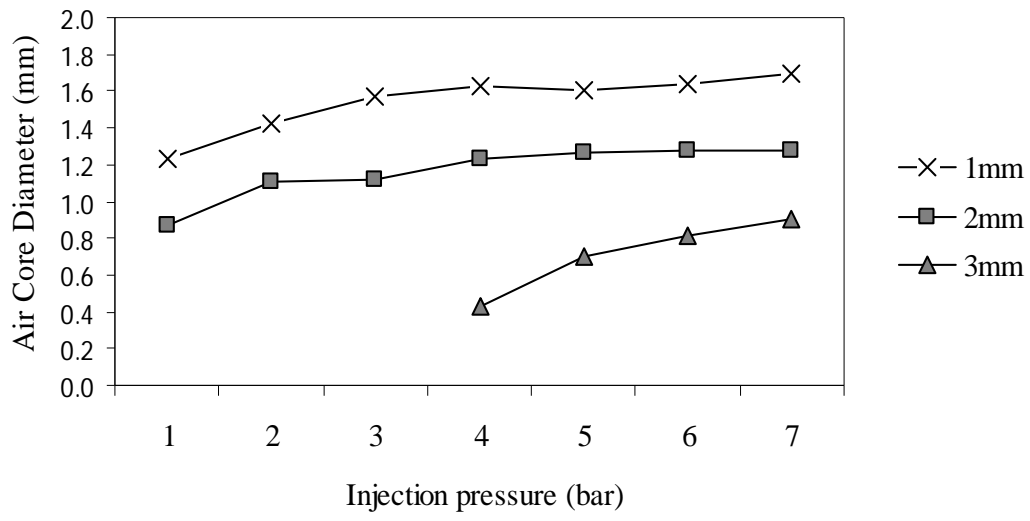

Fig. 9: Effects of injection pressure and diameter of tangential ports on air core diameter.

\section{CONCLUSIONS}

A cold flow test was conducted to evaluate the performance of hollow cone swirl injectors which is to be applied as rocket injector. A total of 49 cold flow tests were completed with two injector parameters varied, which are number of tangential port and diameter of tangential port. Injector performance was based upon spray cone angle and air core diameter as a function of injection pressure.

It can be concluded that higher injection pressure leads to wider spray cone angle and larger air core diameter. Furthermore, the effect of injection pressure on spray cone angle is more prominent for injector with least number of tangential ports. 
In overall, injector with the most number of tangential ports produces widest resulting spray and smallest air core diameter. It can also be concluded that injector with the smallest tangential port diameter produces the widest spray cone angle and largest air core diameter.

\section{ACKNOWLEDGEMENT}

The Ministry of Higher Education (MOHE) kindly provided funding for the research through the "Fundamental Research Grant Scheme" (FRGS) PROJECT NO 600-RMI/ST/FRGS 5/3/FST (125/2010).

\section{REFERENCES}

[1] G. N. Laryea and S.Y. No, "Spray angle and breakup length of charge-injected electrostatic pressure-swirl nozzle. Journal of Electrostatics, pp. 37-47, 2003.

[2] Y.I. Khavkin, "Theory and practice of swirl atomizers". Taylor \& Francis, New York, 2004.

[3] M. R. Halder, S. K. Dash, and S. K. Som, "A numerical and experimental investigation on the coefficients of discharge and the spray cone angle of a solid cone swirl nozzle". Experimental Thermal and Fluid Science, Vol. 28, pp. 297-305, 2004.

[4] A. Datta and S. K. Som, "Numerical prediction of air core diameter, coefficient of discharge and spray cone angle of a swirl spray nozzle". International Journal of Heat and Fluid Flow, Vol. 21, pp. 412-419, 2000.

[5] A. Hussein and R. Atan, "Spray characteristics of jet-swirl nozzles for thrust chamber injector". Aerospace Science and Technology, Vol. 13, pp. 192-196, 2009.

[6] M. R. Soltani, K. Ghorbanian, M. Ashjaee and M. R. Morad, "Spray characteristics of a liquidliquid coaxial swirl atomizer at different mass flow rates". Journal of Aerospace Science and Technology, pp. 592-604, 2005.

\section{NOMENCLATURE}

$\begin{array}{lll}d_{s} & \text { Swirl chamber diameter } & \mathrm{mm} \\ d_{a} & \text { Air core diameter } & \mathrm{mm} \\ d_{o} & \text { Orifice diameter } & \mathrm{mm} \\ d_{p} & \text { Tangential port diameter } & \mathrm{mm} \\ n & \text { Number of tangential port } & - \\ V & \text { Velocity } & \mathrm{m} / \mathrm{s} \\ \psi & \text { Spray cone angle } & - \\ r & \text { In radial direction } & \\ z & \text { In axial direction } & \\ \theta & \text { In azimuthal direction } & \end{array}$

